\title{
Should I Stay or Should I Go? Switzerland and the European Economic and Monetary Integration Process
}

Guillaume Vallet

Université Pierre Mendès-France de Grenoble

\begin{abstract}
The case of Switzerland appears to be unique with regard to the European Economic and Monetary Integration Process which began in 1957: even though the country has cultivated close ties and growing links with the European Union (EU) over time, it does not desire full membership. If this situation of "non-adhesive integration" seems to be beneficial for Switzerland in many respects, it also presents some constraints. Such a position leads to a national dilemma for Switzerland with regard to the EU: should I stay or should I go? Thus we shall examine in this article the particularities, the advantages, and the constraints of the Swiss stance.
\end{abstract}

JEL Classifications: E58, F15, F31

Key Words: Switzerland, European Union, Economic and Monetary Integration

\footnotetext{
* Corresponding Author: Guillaume Vallet; Centre de Recherche en Economie de Grenoble, Université Pierre Mendès-France de Grenoble, Faculté d'Economie 38 040, Grenoble Cedex 9, France, guillaume.vallet@upmf-grenoble.fr. 


\section{Introduction}

The current Greek "tragedy" is indicative of both the success and the difficulties of the economic and monetary integration process in Europe since the Treaty of Rome in 1957. On the one hand, Greece's accession to the Euro Area allowed the country to appear more credible to financial markets, which lowered long term interest rates in Greece from 2001 to 2007 and also maximised its trade with its European partners. On the other hand, among other problems, its Euro Area membership prevents Greece from using monetary policy to sustain its national economic activity due to its delegation of monetary sovereignty to the European Central Bank (ECB) implied in this process. Thus this membership seems to be harmful now because of the country's economic specialisation and especially current investors' loss of confidence in Greek government bonds. Those problems may well require a devaluation process, which Greece is currently unable to resort to.

Thus, this situation seems to prove that the "reluctant Europeans" within the European Union (EU) such as Denmark, Great Britain, Sweden, or the Czech Republic have chosen the correct course, because these countries have not fully partaken in European economic and monetary integration. In other words, they are highly integrated into the European internal market but they also maintain - to some extent - their monetary autonomy, allowing them to focus their monetary policy on their national economy's needs. In the same way, and perhaps more so, this is the case in Switzerland: the country is highly linked to the EU and to the countries belonging to the Euro Area, in particular from an economic and financial perspective, but does not desire to become a full member. This de facto integration without de jure accession reflects the Swiss philosophy as far as its European external policy has been concerned since 1957. In spite of the fact that its main economic partners are EU members, Switzerland wants to preserve its political independence from the EU because the country fears that such accession may harm the very economic basis which has created the "Swiss exception" called Sonderfall.

Also, from the EU's political authorities' point of view, Switzerland is an important partner due to its high level of Gross Domestic Product (GDP) per capita, which offers stability in Europe in economic and financial fields. The EU has therefore accepted a "third way" for Switzerland between accession and full independence because the EU and Switzerland have been linked by various bilateral agreements since 1972. That is why some claim that Switzerland is a free rider: the country benefits from the European collective goods without giving up any domestic particularity for the whole. This seems to be beneficial for Switzerland because its European external trade is secured and the Swiss government maintains fiscal and monetary policies in his hands. If this is right, this would raise issues about the unity and the uniqueness of the European economic and monetary process, because it would show that "there is life" outside the EU and the Euro Area. Consequently, considering the Swiss case, we shall raise this issue: is it really beneficial to be in such a situation or should full accession be preferred? 
This article tries to tackle this issue by answering the above question. This recalls the historic particularities of Switzerland's position within the European Integration Process, which seems to be a paradox because of the Swiss high level of integration without full membership (I). But if this position allows Switzerland to be linked to the EU without giving up its fiscal and monetary policy, which is beneficial, it is also fragile. This article then deals with the viability of this particular situation of "non-adhesive integration" (II).

\section{A. Switzerland, a "Tolerated Outsider" in the European Integration Process}

In order to comprehend the particular relationship between Switzerland and the EU, it is necessary to understand the characteristics of the Swiss experience of "non-adhesive integration" first, and thereafter to explain why Switzerland is reluctant to accede to EU membership.

\section{Switzerland, Embedded in the EU although without being a Full Member}

If we refer to Krugman (1991), countries that are geographically and economically close trade a great deal because of such proximity. They are able to negotiate more at a regional than at a global level. From a purely economic point of view, there are some gravitational effects between those economies which are "natural trading partners." This makes the set-up of a free trade area or bilateral agreement easier and more sustainable because the costs tend to be less. In particular, trade diversion will be limited, which can explain why so many free traders support this kind of preferential trade area (Viner, 1950). All in all, economies which are alike have close economic relations, which may facilitate the setting up of a preferential trade network. From an institutional point of view, the founding of an agreement or a free trade area ratifies what exists de facto as far as trade is concerned. The countries are eager to open their markets regionally, but reluctant to do so multilaterally. That is the conclusion of Veltz in his “Archipelago theory" (Veltz, 1996).

From this perspective, Switzerland, which is located in the EU's and even in Europe's core, is a "natural trading partner" of the EU, given the numerous and intense economic and financial exchanges between them: one job out of three in Switzerland depends on Swiss exports to the EU, and Switzerland is the second greatest export market for EU countries, just after the United States of America. Also, nearly $45 \%$ of Swiss foreign direct investment (FDI) goes to the EU. Switzerland is the EU's third largest export market and the fourth largest source of all imports as well. It is important to highlight that given Switzerland's geographical position in Europe (the "core"), the EU needs to have access to Swiss territory for the transport of goods between various countries (such as Germany and Italy).

\footnotetext{
'As we explain infra, Switzerland and EU signed bilateral agreements in 1999. Among them the question of transport was addressed.
} 
Even though their relations are bilateral, Swiss dependence on the EU is greater due to the country's relatively small size. Switzerland has even known a growing economic and financial dependence on the EU and on the Euro Area in particular. Numerous enlargements with the EU and the deepening of the relations inside it have given the internal market a growing importance for Switzerland. Figures 1 and 2 below demonstrate this phenomenon, as do tables 1 and 2 thereafter:

Figures 1. Swiss Exports to the EU (1963 2010)

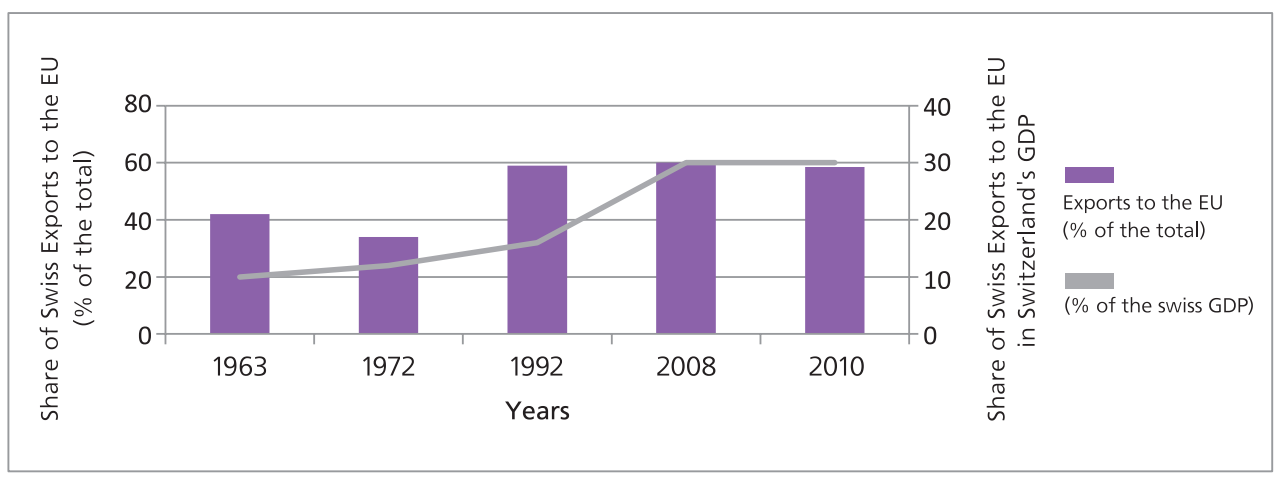

Source : The Swiss National Bank (2011).

Figures 2. Swiss Foreign Direct Investments to the EU (1993 2010)

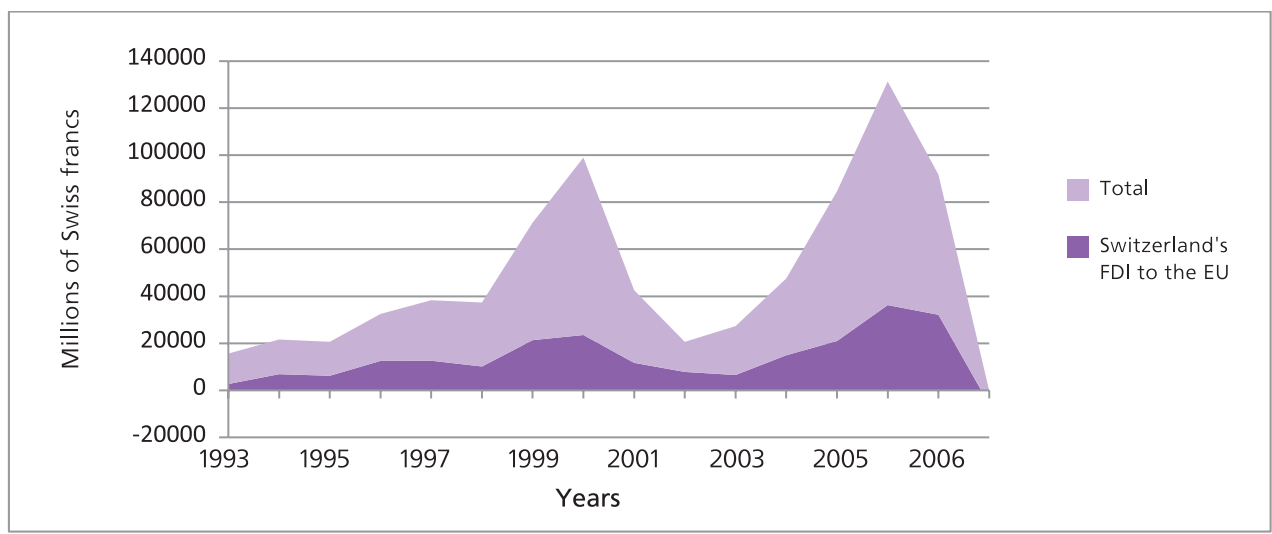

Source : The Swiss National Bank (2011).

This explains why Switzerland has accepted, even though it is not a member of the EU, to contribute to the European Federal Budget, in particular to share the cost of its enlargement to less developed countries (Eastern European countries and Poland essentially). For example, when the EU enlarged to include ten new countries in 2004, the EU asked Switzerland to par- 
ticipate with 100 million Swiss francs a year (Federal Council, 2006). That is the price to pay for access to the EU internal market, even if this amount is lower than full membership would entail (more than 200 million Swiss francs a year).

Table 1. Swiss Commercial Dependence

\begin{tabular}{crrrr}
\hline & 1995 & 2000 & 2005 & 2009 \\
\hline France & 10.78 & 10.01 & 9.51 & 8.54 \\
Germany & 29.27 & 25.58 & 26.09 & 26.37 \\
Italy & 9.17 & 8.51 & 9.59 & 9.73 \\
Spain & 1.67 & 1.97 & 3.14 & 2.27 \\
Portugal & 0.59 & 0.39 & 0.34 & 0.30 \\
EU 15 & 71.74 & 66.71 & 68.49 & 63.94 \\
EU 27 & 73.34 & 68.82 & 71.36 & 66.96 \\
Euro Area & 63.77 & 59.61 & 61.95 & 59.25 \\
\hline
\end{tabular}

Note: Commercial dependence is defined by the ratio between the sum of Switzerland's exports and imports with its partner and the sum of Switzerland's total exports and imports.

Source: Guillaumin and Vallet (2011)

Table 2. Commercial Intensity

\begin{tabular}{ccccc}
\hline & 1995 & 2000 & 2005 & 2009 \\
\hline France & 1.92 & 2.05 & 2.06 & 1.96 \\
Germany & 2.95 & 3.15 & 3.06 & 3.11 \\
Italy & 2.16 & 2.25 & 2.60 & 2.83 \\
Spain & 0.82 & 0.91 & 1.30 & 1.02 \\
Portugal & 1.02 & 0.75 & 0.68 & 0.65 \\
EU 15 & 1.81 & 1.90 & 1.92 & 1.90 \\
EU 27 & 1.75 & 1.83 & 1.83 & 1.77 \\
Euro Area & 1.95 & 2.06 & 2.07 & 2.04 \\
\hline
\end{tabular}

Note: Commercial intensity is defined by the ratio between commercial dependence and Switzerland's share of commercial trade (exports and imports) in the worldwide commercial trade.

Source: Guillaumin and Vallet (2011).

Otherwise, this high and growing degree of integration demonstrates the situation of dependence of small states to close regional economic blocs like the EU. More precisely, as Switzerland is strongly attracted by the main EU and Euro Area's Economies - that is its neighbors such as France, Germany, and Italy, whose GDP represents 75\% of the Euro Area's 
GDP - EU and Euro Area membership would appear "natural" from a Swiss perspective. In other words, if we follow the classic theoretical framework of the economic and monetary integration process, the Swiss case appears to be a puzzle. Indeed, Balassa's pioneer analysis (1961) shows under the heading "dynamics effects of integration" that as economic integration increases, barriers of trade between national markets diminish. Balassa believes that a step in any integration process calls for another step with a higher level of integration. That is why the setting up of a free trade area between countries naturally generates demand for further integration, not only economically but also politically: a free trade area generates a custom union, which lead to the creation of a common and internal market as well as monetary and political union. Thus, economic communities evolve into political unions over time. If reality is not the same as what the model predicts, this theory illustrates the process of economic, monetary, and political integration which has been at work for more than 50 years in Europe with the EU.

The "domino theory of regionalism" (Baldwin, 1993), which is another potential explanation for regionalism in Europe, fails to explain the Swiss case. In this theory, idiosyncratic incidents of regionalism trigger a multiplied effect that knock down bilateral import barriers like a row of dominos. The basic idea is that forming a preferential trade area, or deepening an existing one, produces trade and investment diversion. This diversion generates new political economy forces in non-participating nations, which entail pressures for inclusion. The pressure increases with the size of the trade bloc, yet bloc size depends on how many nations join. Indeed, since new discrimination lowers non-member firms' profit, closer integration stimulates exporters to engage in greater pro-integration political activity. If the government was indifferent to membership initially, the extra activity may tilt the balance, causing the country to join. If it does, the bloc enlarges and the expense of non-membership increases.

Clearly, ${ }^{2}$ then, a single incidence of regionalism may trigger several rounds of membership requests from nations that were previously happy as non-members. If the trade bloc is open to expansion, regionalism may spread like wildfire. In the case of a free trade area, enlargement harms non-member firms by lowering the costs of a new set of rivals. In the case of a customs union or an internal market, an extension of the common external tariff may cause further harm. All this encourages a second-round of pro-integration political activity which may enlarge the bloc further. If the enlargement 'burn-path' is barred, the new political economy flames may find vent in preferential arrangements among excluded nations.

Finally, we could not fully understand the Swiss case in the light of the traditional analysis of the optimal currency areas theory, which refers to the "pioneering phase" (Mongelli, 2002) from the early 1960s to the early 1970s which includes the works of Mundell (1961) and McKinnon (1963). Their theory's framework supposes fixed economy prices and thus emphasizes demand and offers shocks as key, whilst identifying nominal with real exchange rates. The

\footnotetext{
In the case of the EU, supposing that the euro will survive. But we can note that some economists are pessimists on this issue. See Saint-Etienne (2011) on this point for example.
} 
central argument of this theory is that a country which contemplates joining a monetary union has to make a cost-benefit analysis. As far as the benefits are concerned, two criteria can be used. On the one hand, the benefit of joining a monetary union can be proxied by the amount and the intensity of trade carried out with the prospective members of a union. On the other hand, countries can consider the frequency of symmetric shocks. In the Swiss case, even more robust econometric tests should be done to sustain efforts in that direction (Vallet, 2010), the high degree of integration perceived in tables 1 and 2 seem to indicate that these two conditions are met, and that the accession to the EU and the Euro Area would be viable.

Nevertheless, Switzerland anticipates many costs of EU membership and monetary union that overtakes the incentives for full accession. That is why the country appears to be a puzzle in the sense that a high level of economic integration has not created spillover effects leading to EU membership, as other European countries have experienced. We shall try to explain this phenomenon by presenting some of the reasons for this reluctant stance.

\section{Why is Switzerland so reluctant to accede to full EU Membership?}

If Switzerland is often described as a particular country, it likes to present itself as such as well. Switzerland is a Sonderfall, which means a special, a rare case. These particularities have to be understood first due to the country's geographical features: as it is a small country that is highly open internationally, Switzerland has been built on a dialectical relationship with the outside from a historical point of view, that is, external markets have been both a source of opportunities and a source of constraints. That is partly why Switzerland fears that the highly institutionalized integration processes imply a substantial loss of sovereignty, because they could jeopardize some of the pillars of the Swiss model. That is the case towards the EU (Gstöhl, 2002). From a political point of view first, Switzerland is leery of the loss of its "national identical triangle" (neutrality, federalism, direct democracy) due to the necessary delegation of sovereignty to the EU's supranational institutions. Indeed this "triangle" has historically lain at the base of Swiss national cohesion and identity. This partly explains why Switzerland has kept its distance from the EU's integration process from the Treaty of Paris in 1951 and from the Treaty of Rome in 1957. In other words, the country has preferred to avoid any loss of political sovereignty while taking into account its economic interests which strongly depend on the EU's developments.

But economic arguments are used as well. First, if Switzerland depends extensively and persistently on the EU's internal market, the country is opened to extra European trade as well. Its openness rate ${ }^{3}$ of $45 \%$ of GDP not only includes exchanges with EU countries, but also with Asian countries and the United States. Swiss exports to the United States represent around 10\% of overall Swiss exports. That means that this country is the second greatest trade partner for Switzerland, just after Germany. Hence we can see that Switzerland is "between two worlds"

\footnotetext{
${ }^{3}$ Which can be defined as the average of exports and imports, as a $\%$ of the GDP.
} 
indicating that the country's situation cannot simply be thought of as European dependence.

From a financial perspective, that is the case as well. Switzerland is an important financial center outside the EU and the Euro Area, in which financial flows are massive with European economic agents but with other nationalities as well. The openness and the relative small size of the country oblige Switzerland to be linked to other financial centers all over the world, for transactions, loans, or borrowing activities. Table 3 demonstrates this:

Table 3. Geographical Distribution of the Financial Assets and Commitments of the Resident Banks in Switzerland in 2009

\begin{tabular}{ccccc}
\hline & \multicolumn{2}{c}{ Financial assets } & \multicolumn{2}{c}{ Financial commitments } \\
\hline & $(1)$ & $(2)$ & $(3)$ & $(4)$ \\
Euro Area & 215467 & 15.3 & 245822 & 18.4 \\
United Kingdom & 344838 & 24.5 & 330733 & 24.7 \\
United States & 380145 & 27.0 & 177906 & 13.3 \\
Japan & 56553 & 4.0 & 17513 & 1.3 \\
Russia & 3801 & 0.2 & 11398 & 0.8 \\
Total & 1403829 & 100 & 1335980 & 100 \\
\hline
\end{tabular}

Note: (1) in millions of Swiss francs (2) in \% of the Swiss total foreign assets (3) in millions of Swiss francs (4) in $\%$ of the Swiss total commitments towards the foreign world

Source: The Swiss National Bank (2009).

Furthermore, beside these elements, Switzerland's specialization in financial activities is a real national structural choice because the country has historically built a large part of its wealth on it. This sector represents $11.2 \%$ of Swiss GDP in $2011^{4}$. In particular, banking privacy allows Switzerland to attract significant amounts of capital flows. In spite of the current financial and political turmoil, which has led to an international official condemnation of banking privacy's existence, Switzerland still maintains it. The country is even the world leader in private banking, with around $30 \%$ of overall global assets under management. For all these reasons, the country's specialization in financial activities is clearly a national structure preference that Switzerland has to preserve.

In this respect, acceding to the EU is seen as a source of jeopardy to some Swiss economic and political elites, as it could lead to "financial trade diversion": the Euro would become the main, even the only currency used for economic and financial transactions in Switzerland while, conversely, the country needs different currencies. While the Euro is certainly one of the most important currencies for Switzerland, it can't be the only one. As table 4 indicates, Swit-

\footnotetext{
${ }^{4}$ Nearly $15 \%$ just before the crisis started in 2007.
} 
zerland realizes many transactions in other important currencies, in dollars particularly:

Table 4. Stock of the Foreign Direct Investments and Foreign Portfolio Investments in Switzerland, Distribution made according to the Different Currencies (2003 2010)

\begin{tabular}{c|c|cccc}
\hline & & \multicolumn{4}{c}{ (millions of Swiss francs) } \\
\hline \hline \multirow{3}{*}{$\begin{array}{c}\text { Foreign Direct } \\
\text { Investments }\end{array}$} & Swiss Franc & 196300 & 229896 & 362172 & -503542 \\
& Euro & 187 & -4985 & 9060 & 230644.4 \\
& Dollar & 4324 & -927 & 15006 & 143329.2 \\
& Other currencies & -145 & -348 & -6343 & 454953.5 \\
\hline \multirow{3}{*}{ Portfolio } & Total & 200666 & 223636 & 379894 & 325385 \\
\hline \multirow{3}{*}{ Investments } & Swiss Franc & 481581 & 694291 & 799514 & -295348 \\
& Euro & 36102 & 43718 & 43909 & 279679.9 \\
& Dollar & 30148 & 36625 & 43483 & 220503.8 \\
& Other currencies & 8960 & 13492 & 15171 & 125086.2 \\
\hline & Total & 566790 & 788126 & 902077 & 329922.3 \\
\hline
\end{tabular}

Source : Swiss National Bank (2011)

Switzerland is then an internationally attractive place for capital whose competitiveness partly depends on the international monetary status of the Swiss franc. Indeed, in connection with direct democracy and the fact that sovereignty belongs to each Swiss citizen, the people of the country closely monitor and control the Swiss government. This eases the balance of public expenses and which, in turn, leads to a low national debt, because the government is much more careful in its actions. In other words, the political control which takes place in this small country has strong and positive economic effects, in the sense that it improves the confidence in investing in Switzerland. It seems that this system is more efficient than that of the EU, as is also the case in other non-EU countries like Norway and even in non-Euro Area countries like Sweden. It is important as well because such a framework creates a reciprocal trust between Swiss citizens and their institutions embodied in the government's policies (Swiss Federal Department of Finance, 2009). It is important to note too that the federalist structure of the country implies a strong supervision and coordination between the federal and cantonal levels of government. Both define and implement rules that help to avoid excessive public deficits and debt (Jeanrenaud, 2001, p 119). Such an efficient organization would have to be integrated into the EU's framework, a prospect that creates doubt in the country.

Furthermore, as the Swiss franc has historically played the role of a safe haven currency (Ranaldo and Söderlind, 2010; Coudert and Raymond, 2011), it induces massive portfolio investment in Switzerland and then a very low cost of capital compared to that of other countries. 
This advantage is even called "interest rates bonus": historically, short nominal and real interest rates as well as long nominal and real interest rates have been lower than those of any EU member since 1957, and even those outside the EU, as graph 3 shows. The current European crisis, along with the rise of long interest rates for some countries, and symmetrically, the decrease of Switzerland's yields due to a strong demand for Swiss bonds, sustains efforts in that direction:

Figures 3. 10 years interest rates (bonds yields)

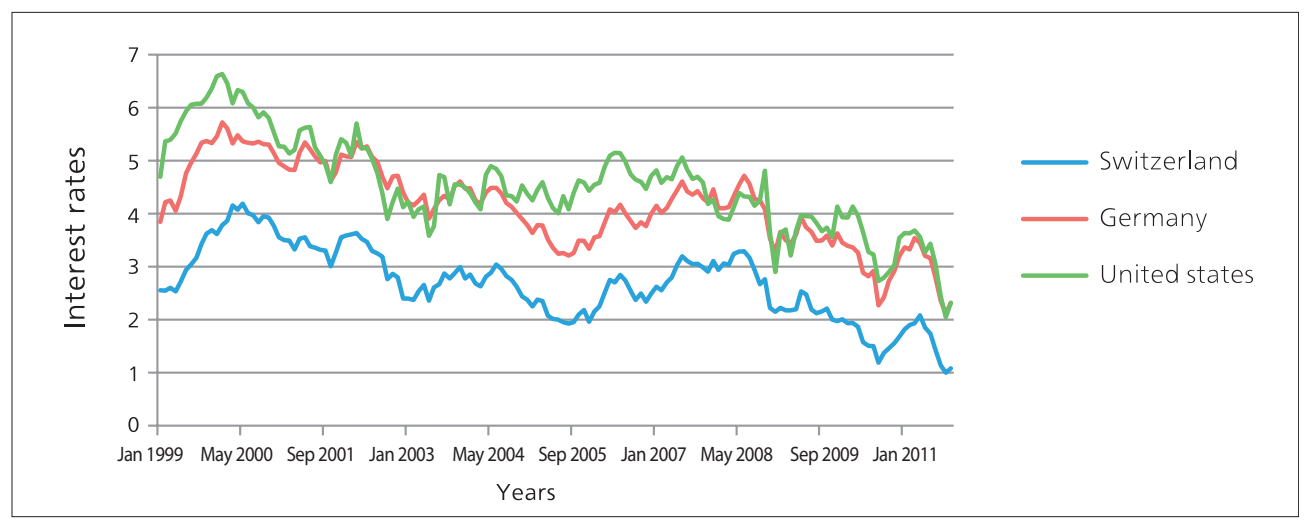

Source: The Swiss National Bank (2011)

In addition, as accession to the EU implies Euro Area membership according to the European Treaties (the so-called "acquis communautaire"), Switzerland would lose its interest rates bonus because the country would have to give up its monetary sovereignty to the European Central Bank (ECB). This would automatically lead to a rise of short term interest rates in the domestic economy, because the ECB's interest rate would be effective in Switzerland. This is a real fear for Swiss competitiveness. Furthermore, even if, in spite of its EU accession, the maintenance of a premium-risk in favor of Switzerland could continue to exist after acceding to membership, Switzerland dreads a rise of long term interest rates as well, because of the link between short and long term rates ("structure of the interest rates"). In this scenario, there would be negative effects on the cost of capital and therefore on investment and growth.

In sum, Switzerland has to preserve its monetary independence and its national currency, because it seems that the Swiss franc's intrinsic characteristics are to a large extent at the source of Switzerland's interest rates bonus. A study conducted by UBS at the beginning of the 2000s (UBS, 2000) showed that $50 \%$ of the bonus could be explained by international investors' confidence in the Swiss franc. They decide to invest in Switzerland and not elsewhere because they want to diversify their placements and to protect themselves from financial risks. Indeed, the Swiss economy and its policy of stability reassure them. Thus, given the relatively small size of the Swiss financial markets, such an increase in capital flows coming into the country leads to a 
rise of the price of Swiss assets denominated in Swiss francs. As indicated just before graph 3, in the bond market in particular, prices have tended to rise and yields have tended to fall. The low level of interest rates is not a problem for investors, because they can borrow more easily and because they have the opportunity to realize a gain over time due to the rise of the assets' prices.

Furthermore, banking circles fear that accession to the EU may lead to the end of banking secrecy in Switzerland, and then to an exit of capital from the country. If it is difficult to measure exactly and specifically the impact of banking secrecy on entries of capital in Switzerland, its existence improves the overall attractiveness of the Swiss economy, whose specialization is financial. Indeed, since the European Council of Feira in 2000, the EU has wanted its new members to exchange some fiscal information in this field; this is why staying outside the EU is essential for Switzerland (Schwok, 2006). International pressure since the 2007 crisis has certainly existed to force Switzerland to accentuate its collaboration with other countries' fiscal authorities or even to give up banking secrecy. This pressure is even perceived as a "Diktat" by banks and financial institution (Schriber, 2007) and that is why the government has to preserve it for the country's competitiveness but also for the trust Swiss citizens place in the respect for private life. So, banking secrecy "has to be maintained" (Swiss Federal Department of Finance, 2009, p 37) in spite of international pressure.

In addition, this is not a specifically European question. Switzerland has been able to negotiate bilateral solutions with various partners which - for the moment - which consist of retaining an amount of the incomes of a foreign person's fortune and then providing a part of it to the fiscal authorities of its country of origin without exchanging any private information. These are the so-called "Rubik Agreements," whose name is inspired by the name of a game whose puzzle cannot be solved. Moreover, not only can this process be time-consuming but only the holdings of individuals are concerned, and not the holdings of institutions, which are important Swiss banking clients.

In sum, in terms of European policy, Switzerland tries to establish strong commercial and financial links with the EU while maintaining economic and political particularities that are presented as essential. The "philosophy" of such a strategy is to push away full accession to the EU as long as integration with the rest of the world is a Swiss priority as well. That is why Swiss relations with the EU during the last fifty years have to be understood not as steps towards membership but conversely as steps away from it.

Thus this explains first why Switzerland preferred access to the European Free Trade Area (EFTA) that arose in 1960, because it represented a way to reinforce economic integration but without giving up political concessions. Switzerland is still a member of it, even though its main member countries (except Norway) have become full members of the EU over time. This EFTA membership is interesting too because it allows the country to freely develop its foreign exchanges in Europe with countries other than those of the EU. Secondly, the Swiss stance makes more understandable the particularity of the agreements that have been signed between 
Switzerland and the EU since which have allowed it to penetrate the European internal market. Their nature and their scope diverge from those between the EU and various third countries that desire access to the European internal market: in the latter case, they are seen as steps towards full membership, but not in the Swiss case. That is why Switzerland prioritized bilateral agreements in 1972 for the trade of industrial goods, and in 1999 and 2004 for other sectors. These agreements satisfy Swiss economic and political circles: to them this is currently the best way as far as Swiss European policy is concerned, and it has to be pursued in the future. They allow the country to avoid the EU's spillover effects and to the Euro Area's ones all the more.

Switzerland apparently contradicts all traditional theories of integration processes. This indicates that the European integration process can take on many different forms without implying the same results. More than a free rider, Switzerland seems to be a tolerated outsider by the EU: because of its neighbor relationships, the EU accepts this situation because it has some interests in it (European market extension, Swiss contribution to the European budget, bargaining on topics like banking secrecy, etc.). All in all, from the Swiss point of view, these kinds of agreements allows the country to preserve the main characteristics of its economy, and monetary autonomy in particular. But is this situation of "non-adhesive integration" really viable for Switzerland? The discussion relative to this question is the object of the next section.

\section{B. Calling the Swiss Position's Viability into Question}

The Swiss position seems a priori to be comfortable and beneficial, in the monetary field in particular: Switzerland benefits from European collective goods without giving up its monetary sovereignty. We call this an "optimized currency area," which we shall detail first. Nevertheless, this is an ambivalent situation: if it brings undeniable advantages to the country, but is fagile. In particular, its viability supposes stability of the Swiss franc/euro exchange rate, a condition rarely achieved because of the country's openness and the potential of appreciation of the national currency.

\section{Is the Swiss "Optimized Currency Area" Interesting and Viable?}

With the launching of the euro in 1999, Switzerland dreaded that the European economic area would work like a closed web, namely with specific internal economic relationships which would be more intense and dense than external ones. Indeed, the country feared overall that such "network effects" and "club effects" would be discriminatory to third party countries: in this case, Swiss integration without accession would not have worked as the Swiss European policy anymore.

Fortunately for Switzerland, these fears do not seem to have been realized. Baldwin (2006) shows that the European single currency has not led to trade creation, more precisely not to the extent that was hoped (Frankel and Rose, 1997). Furthermore, given that trade creation has 
also affected third countries near the Euro Area like Switzerland, this means that not only is the European monetary network not closed, because it benefits members and non-members, but the advantages are the same for both. Indeed, according to Baldwin, if trade creation thanks to the euro is about $10 \%$ on average for the whole area, it is about $5 \%$ for Germany, $16 \%$ for Spain, $4 \%$ for Italy, and $10 \%$ for the United Kingdom, while it is $4 \%$ for Sweden and Denmark, and $12 \%$ for Switzerland.

Thus the Swiss position is, in this analysis, beneficial and viable. A full membership would entail higher costs without any significant benefits. Conversely, not being a member of the Euro Area allows the country both to benefit from the dynamism of trade with the Euro Area while maintaining the possibility of using monetary policy for internal needs. To make this situation last, beside institutional reassurances from the EU thanks to bilateral agreements, it is necessary for Switzerland to bring its internal economic rights closer to the EU's ones. Indeed, to share a high convergence in those fields would lead to a better synchronicity of business cycles without being disturbed by the exchange rate. Also, given the Euro Area's attraction to Switzerland, the country benefits from the Euro Area's economic activity.

In the same way, without supporting all of the costs, Switzerland takes advantage of the monetary and financial efforts realized by the Euro Area's countries. The prospect and thereafter the launching of the euro have ended monetary "laxness" of many countries, which used to lead to a high and volatile level of inflation, with negative effects on exchange rates. In spite of the Euro Area's current problems, which seem to have more economic and political sources than monetary ones, the euro has stabilized Europe in the monetary field. This advantages Swiss border consumers in particular and Swiss exporting companies as well because of a more stable monetary environment implying less price distortion. They have been able, since 1999, to use only the euro in their transactions with the Euro Area's countries instead of using a lot of different currencies, as had been used before. Thus foreign exchange risk is lower and economic forecasts are better, which means higher competitiveness.

Switzerland benefits from this more stable monetary universe in terms of monetary policy because it can refocus on internal economic fundamentals and maintains its autonomy. As Switzerland is a small open economy strongly dependent on trade with the Euro Area, if the exchanges are more stable and more predictable, imported inflation is lower. This makes it easier for the Swiss National Bank (SNB) to achieve its main objectives and to implement its monetary policy. In the financial field, it is the same: Switzerland benefits from the EU's developments without supporting all of the costs. This is important because a high degree of economic integration entails spillover effects in terms of financial integration.

Indeed, the economic integration process, removing national boundaries, easies trade of goods, services, labor, and capital, in particular capital flows in the financial market. Symmetrically, if the financial integration process has its own logic and autonomy, it facilitates daily transactions as well thanks to a unique and unifying payments system: any trade of goods and services between tied countries entails real flows, but also financial and monetary ones, which 
are their counterparts. Thus Switzerland has to participate in the European financial integration process, given its specialization and its economy's geographical orientation.

That is why, for example, Switzerland really wanted to integrate into the Single European Payments Area (SEPA), namely the Euro Area's unique mass payments system, while the country was not a full member of it. Switzerland has been connected to it since 2006, and Swiss banks are full members of the European Payments Council (EPC). Moreover Swiss banks are major actors within it, and are on an equal footing with the Euro Area's banks. 300 Swiss banks participated in it in 2010. With the SEPA, Switzerland certainly has had to accept the EU's and EPC's rules when its banks use the euro in their transactions inside the Euro Area. But on the other hand, Switzerland is not subject to the EU's regulations and directives. Swiss financial integration into the EU and the Euro Area is then partial and again allows the country to benefit greatly from a collective good without supporting all of the costs. The EU agrees with this situation because Swiss integration increases and densifies the European financial network, which improves financial stability. If Switzerland has had to support some costs - around 100 million Swiss francs - its participation has still be beneficial. Financial sovereignty has improved Swiss financial performance and fundamentally reinforces its institutional independence from the EU.

To sum up, Switzerland seems to be one of the European countries which have benefited the most from European economic, financial, and monetary integration while not being an EU member. Its de facto integration allows Switzerland to take advantage of the EU's stability and dynamism. Moreover, while previously relatively distant from the business cycles of the Euro Area's core, Swiss business cycles have become closely linked to the Euro Area's over the time, with a high synchronicity. Such a high level of synchronicity creates the conditions of proximity between Swiss and European monetary conditions, while giving Switzerland sufficient autonomy to implement a monetary policy concerned with internal needs. That is the same as far as the European financial process is concerned: the essential goal for Switzerland is to be sufficiently "closed to Europe" to manage to participate in the EU's main developments, but without entailing a strong and unique dependence towards the EU, and while preserving Swiss financial particularities. Due to this particular position of "non-adhesive integration," which implies both strong business cycles synchronicity between Switzerland and the Euro Area and monetary autonomy, we can say that Switzerland is located in an "optimized currency area."

In other words, possessing these optimal currency area criteria does not necessarily lead to monetary union. On the contrary, thanks to its de facto links with the EU and the Euro Area, Switzerland does not need to become a full member. This situation allows the country to focus its monetary policy on internal priorities while avoiding external disturbances. But the condition would that make it possible for such an "optimized currency area" to exist in the long run for there to not be any strong movement of the Swiss franc/euro nominal exchange rate. Indeed, given Switzerland's high degree of de facto economic integration with the EU, strong and longlasting disturbances on this parity would jeopardize the Swiss economy and the SNB's ability 
to implement an autonomous monetary policy. Moreover, such an "optimized currency area" can only exist if investors anticipate sufficient convergence between Switzerland and the EU. If not, they could test the Swiss franc/euro exchange rate's stability, and then create speculation trends in the markets. The problem is that this exchange rate constraint regularly arises for Switzerland, as the current crisis shows. Thus let us end our essay with this particular issue.

\section{The Helvetian Achilles' Hell: the Historic Problem Exchange Rate Appreciation}

Swiss contemporary monetary history has been marked by frequent movements of the Swiss franc against other currencies, often appreciation. This is true about the Swiss franc's fluctuations against the main international currencies, both in effective, nominal, and real terms. The Swiss franc had tended to appreciate strongly against the dollar and the euro, which represent respectively a share of $15 \%$ and $62 \%$ in the level-headedness of the nominal and real effective exchange rates. This appreciation against these two currencies is longstanding: already in the 1930's the Swiss franc was appreciating against the dollar and the main European currencies that have merged in the Euro so far (Bordo et al. 2006), and this was also the case in the Bretton Woods System in real terms.

Since the beginning of the current crisis, the Swiss franc has tended to nominally appreciate the most against the dollar, the yen, and, especially recently, the euro, as we can see in graph 4 below, where a decrease in the curves indicates an appreciation of the Swiss currency:

\section{Figures 4. Swiss Franc Nominal Exchange Rates}

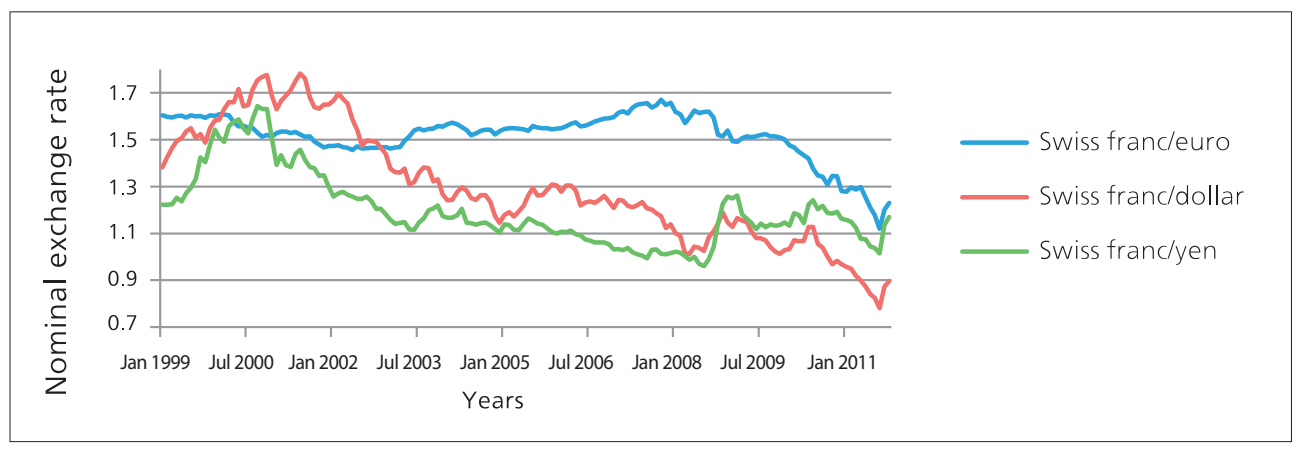

Source: The Swiss National Bank (2011)

Two kinds of explanations can be mobilized here to comprehend such an appreciation. In the long term, the importance of the current account surplus (between $10-15 \%$ of GDP a year since the 1990's) implies an abundance of capital flows for Switzerland. This leads to an appreciation of the Swiss franc because of the heightened demand for this currency. In the short term, and that is what is interesting here, the appreciation is due to two main reasons. First this is due to the fact that the Swiss franc is a safe haven currency which attracts investors in case of inter- 
national disturbances (Cairns et al., 2007; Ranaldo and Söderlind, 2010; Coudert and Raymond, 2011). This is a historic trend. Indeed, international investors who are looking for a stable environment find it in Switzerland because of its economic, monetary, fiscal, and political stability, and because of its institutional particularities like banking secrecy. When the capital inflows are massive, they lead to a sudden increase in demand for Swiss franc assets. Given the fact that the Swiss financial markets are relatively small, the prices of the assets tend to be higher, and so on for the Swiss franc when compared to other currencies. This explains why during the current crisis the Swiss franc had appreciated, and not because of Swiss monetary policy (Lenz and Savioz, 2009), even though Switzerland is not at the core of the international disturbances (Kohler, 2010).

Secondly, the Swiss national currency has appreciated since 2007 because of the end of an international carry trade in which the Swiss franc was a major international financing currency. Indeed, before 2007, there was an important short term interest rate differential between the Swiss' and other developed countries'. This situation incited investors to borrow in Swiss francs and then convert and invest these loans in assets in other currencies (investment currency) where there were higher interest rates. Anticipating stability of the exchange rate between relevant currencies, the investors anticipated a significant capital gain. But the problem is that such behavior leads to a strong deprecation of the financing currency, followed thereafter by strong appreciations when the investors change their positions. That is what happened to the Swiss franc against the euro: after a decrease against the single European currency from 2003 to 2007, due to lower interest rates in Switzerland than in the Euro Area leading to carry trade behavior, the Swiss franc appreciated strongly and quickly when the European Central Bank (ECB) lowered its interest rates because of the crisis. This is exactly what Frankel (2007) has demonstrated for the movements of carry trade's financing currencies.

The problem for Switzerland is that such appreciations of the Swiss franc against the euro in particular could disturb the national economy due to the high degree of Swiss integration with the EU and the Euro Area. Indeed, as the EU is Switzerland's main partner, as the economic degree of openness is high, and as the share of the euro in the nominal exchange rate $(62 \%$ as indicated), this parity is central for the country. There must be an existing high Swiss franc/ euro exchange rate pass-through in Switzerland, revealing that the European country's position is fragile. Nevertheless, econometric studies are divided on this question. On the one hand, authors like Fisher (1999) or Stultz (2007) show that it is difficult to establish strong evidence of such disturbances for the Swiss economy due to exchange rates movements. Fisher indicates that Swiss external trade is not affected by Swiss franc volatility on the whole, while Stultz demonstrates that exchange-rate pass-through to import prices and then to national prices tends to have diminished in Switzerland since the 1990's. As it is underlined by their authors, these conclusions do not indicate that Swiss franc movements have no influence on the national economy. They only show that for some sectors or macroeconomic variables the effect of this volatility has been mitigated. 
On the other hand, other studies conclude that the Swiss franc's appreciation against the euro exerts negative effects on Switzerland, via the external trade channel. More than appreciation as such, it is crossed levels by parity that seem to be problematic: it is not the same for exporters when the Swiss franc / euro exchange appreciates from 1 euro / 1.65 Swiss francs to 1 euro / 1.45 Swiss francs and from 1 euro / 1.45 Swiss francs to 1 euro / 1.25 Swiss francs. To sustain efforts in that direction, different econometric studies indicate the loss for the Swiss economy given the national currency's appreciation against the euro, as indicated in table 5:

Table 5. Effects of a Swiss Franc/Euro Exchange Rate's Appreciation on Swiss Exports

\begin{tabular}{ccccc}
\hline Studies & Aggregates & Short Term Effect & Long Term Effect & Maximum Effect \\
\hline Aeppli (2008) & Goods Exports & $-0.3 \%$ & & \\
SECO (2007) & Goods Exports & $-0.5 \%$ & $-1 \%$ & 5 years \\
KfK (2003) & Total Exports & De -0.3 à $-0.4 \%$ & & \\
Lampart (2006) & Total Exports & $-0.2 \%$ & $-0.7 \%$ & 3 years \\
\hline
\end{tabular}

Source: Lampart (2011)

Moreover, the tourism sector was strongly affected by such an appreciation in 2011, as far as the sector of commerce and distribution: not only are foreigners now reluctant to go to Switzerland because of a loss of purchasing power - even though the average level of Value Added Tax, about $7.5 \%$, is lower in Switzerland than in the EU - but Swiss people conversely buy more products in the European areas near the boundaries of the country and less in Switzerland, due to Swiss franc appreciation. This leads to weak economic activity in some parts of the country.

The SNB is in this case also undermined in its capacity to implement a monetary policy focused first on the internal needs of the economy. Indeed, although the SNB has for several years faced deflationist pressures which would necessitate a depreciation of the exchange rate to lower short term interest rates, SNB has not been able to apply such measures due to their existing very low level. They are close to $0 \%$ in nominal terms, which means that they are negative in real terms. It can also set up "non-conventional policies" like interventions in the foreign exchange market to buy euros with the aim of lowering the Swiss franc/euro parity. But the problem is that this kind of measure is risky, with limited effects, and overall it is costly. Since March 2010, the SNB has sold 100 billion Swiss francs on the foreign exchange market, in particular to buy euros. Its balance sheet has increased and has degraded because of the owning of assets in euros. Its liabilities, which have increased, could be a future source of inflation in the country.

So we can see to what extent the Swiss "optimized currency area" in Europe can be disturbed and jeopardized in the case of strong and sudden appreciation of the Swiss franc against 
the euro. This explains why the SNB decided on September $6^{\text {th }} 2011$ to define a threshold below which the Swiss franc/euro parity would not be allowed to fall. Since then the SNB has engaged its responsibility to maintain the exchange rate above 1 euro to 1.20 Swiss francs. This measure reflects Switzerland's European policy that has been implemented since the beginning of the European integration process: being sufficiently open to the EU's development but to avoid full membership. This means pragmatism, advantages, and risks, but such are the characteristics of a small open economy.

\section{Conclusion}

Switzerland and the EU have had a close but particular relationship since the beginning of the European integration process, which started in 1957 within the framework of the EU. Due to the fact that Switzerland does not want to accede to the EU as a full member for both political and economic reasons, the country has developed a European integration stance not only different in terms of degree but also in terms of nature in comparison to other third party) countries linked to the EU. In other words, Switzerland privileges "non-adhesive integration" which suits its interests. But, on the other hand, Switzerland's strong economic dependence on the EU constraints the country to institutionalize that relationship, which implies certain losses of sovereignty. The different and numerous bilateral agreements existing between Switzerland and the EU symbolize this particular stance. Thus it seems that Switzerland participates in an "optimized currency area," which allows the country to push away EU full membership and reinforces the country's competitiveness.

Nevertheless, such pragmatism and efficiency in its external policy have some limits. In particular, the country is exposed to movements of the Swiss franc exchange rate. This is the case for Swiss franc/euro parity, which leads to a decrease of certain industrial goods exports and undermines the SNB's ability to implement a monetary policy oriented towards the internal needs of the Swiss economy. Then, the Swiss case perfectly illustrates the advantages and the costs of being a small open economy in the current globalization process. It also reveals that in order to obtain a greater benefit, in the context of accelerated catching by emerging countries, each country has to define and to choose a "national preference structure" to improve its performance. For Switzerland, as the banking and financial sectors play this role, it is central to preserve their particularities. This partly explains why the country is so determined to preserve banking secrecy, although Switzerland is criticized by the international community for this reason: banking secrecy is not only a national "brand" for the Swiss economy as in other countries (Cayman Islands) or in parts of the states (Delaware or Miami in the United States of America; the Channel Islands in Great Britain for instance), but also for the Swiss identity as a whole. In other words, banking secrecy is one of the determinants of internal (Aglietta and Orléan, 2002) 
and external (Helleiner, 2008) confidence in the national currency, which is very important for a small open economy and most of all, a country with multiple internal identities like Switzerland.

Received 21 December 2011, Revised 25 April 2012, Accepted 02 June 2012

\section{References}

Aglietta, M. and Orléan, A.,2002, La monnaie entre violence et confiance, Editions Odile Jacob, Paris.

Balassa, B., 1961, The theory of economic integration, Homewood, Illinois.

Baldwin, R., 1993, “ A Domino Theory of Regionalism ”, NBER Working Papers, n4465, September.

Baldwin, R., 2006, “ In or Out: Does It Matter ? An Evidence-Based Analysis of the Euro's Trade Effects ", Centre for Economic Policy Research, London.

Banque Nationale Suisse, 2009, "Comptes financiers suisses".

Bordo, M., Helbling T., and James H., 2006, "Swiss Exchange Rate Policy in the 1930's. Was the Delay in Devaluation too High a Price to Pay for Conservatism?", NBER Working Papers, n¹2491, August.

Cairns, J., Ho, C., and McCauley, R., 2007, “ Exchange rates and global volatility: implications for Asia-Pacific currencies”, BIS Quarterly Review, March, pp 41 - 52.

Coudert, V. and Raymond, H., 2011, " Gold and Financial Assets: Are There Any Safe Havens in Bear Markets”, Economics Bulletin, vol. 31 (2).

Federal Council, 2006, Rapport Europe2006, Berne, June $28^{\text {th }}$.

Fisher A., 1999, "Les effets de la volatilité des changes sur le commerce extérieur de la Suisse : estimations à partir d'un modèle à variables multiples", Bulletin trimestriel de la BNS, 2.

Frankel, J. and Rose, A., 1997, “ TheEndogeneity of the Optimum Currency Area Criteria ”, NBER Working Papers, ${ }^{\circ} 5700$, September $24^{\text {th }}$.

Frankel, J., 2007, "Getting Carried Away: How the Carry Trade and Its Potential Unwinding Can Explain Movements in International Financial Markets", Milken Institute Review, November $19^{\text {th }}$.

Gstöhl, S., 2002, Reluctant Europeans.Norway, Sweden and Switzerland in the process of integration, Lynne Rienner Publishers, London.

Guillaumin, C. and Vallet, G., 2011, « La Suisse et la zone euro : votre monnaie, notre problème ? La possibilité d'un ancrage de jure », Cahiers de recherche du CREG, n03, Juillet.

Helleiner, E., 2008, "Political Determinants of International Currencies: What Future for the US Dollar?", Review of International Political Economy, 15(3), pp 352-376.

Jeanrenaud, C., 2001, « Conséquences d'une intégration à l'Union européenne pour la politique financière des cantons », in Aubert J.F., Jeanrenaud C., Pfisterer T., Schweizer R.J, Sturny T. and Thürer D., Les cantons face au défi de l'adhésion à l'Union européenne, Schulthess, Zürich. 
Kohler,M., 2010, “Exchange ratesduringfinancialcrisis “, BIS Quarterly Review, March, pp 39 - 50.

Krugman,P., 1991, “The Move toward Free Trade Zones”, Economic Review, Federal Reserve Bank of Kansas City, pp. 7-58.

Lampart, D., 2011, « Effets d'une appréciation du franc sur l'économie suisse », Union Syndicale Suisse, $w w w$. uss.ch, Dossier $n^{\circ} 71$, janvier.

Lenz, C. and Savioz, M., 2009, “ Monetary Determinants of the Swiss Franc ”, Paper presented at Annual Conference of the Swiss Society of Economics and Statistics, February $13^{\text {th }}$, Lausanne.

Mac Kinnon, R., 1963, “Optimum Currency Areas”, American Economic Review, Volume n 53.

Mongelli, F.P., 2002, “New views of the Optimal Currency Area theory: what is EMU telling us ?”, Working Paper, $\mathrm{n}^{\circ}$ 138, European Central Bank, April.

Mundell, R., 1961,“A Theory of Optimum Currency Areas ”, American Economic Review, Volume n51.

Ranaldo, A. and Söderlind, P., 2010, “Safe Haven Currencies ”, Review of Finance, vol.14 (3), pp 385-407.

Saint-Etienne C., 2011, La fin de l'euro, Paris, François Bourin Editeur.

Schriber, M., 2007, Le secteur bancaire suisse : une histoire à succès, mais aussi à risque, Revue de politique économique, $\mathrm{n}^{\circ} 4$, pp $44-48$.

Schwok, R., 2006, Suisse-Union européenne, l'adhésion impossible?, Presses polytechniques et universitaires romandes, Collection Le savoir suisse.

Stultz J., 2007, "Exchange rate pass-through in Switzerland: Evidence from vector autoregressions", Swiss National Bank Economic Studies.

Swiss Federal Department of Finance, "Strategic Directions for Switzerland's Financial Market Policy”, 2009, Report in Response to the Graber Postulate, September, Bern.

Vallet, G., 2010, « La Suisse et la zone euro: une zone monétaire optimisée ? », Revue du Marché Commun et de l’Union européenne, n543, décembre, pp $624-635$.

Vetz, P., 1996, Mondialisation, villes et territoires, l'économie d'archipel, Paris, PUF, Economie en liberté.

Viner, J., 1950, The Customs Union Issue, Carnegie Foundation for International Peace, New York.

UBS, 2000, “ The Future of the Swiss Franc. Independence or clinging to the euro boat ?", UBS Group Economic Research Studies, October. 